\title{
Experimental Study on the Removal of Arsenic in Waste Water from Semiconductor Manufacturing
}

\author{
Yue LI*, Min XI, Fanlong KONG, Chunyan YU \\ College of Chemical and Environmental Engineering, Qingdao University, Qingdao, China, \\ E-mail: qdenv@126.com \\ Received February 10, 2009; revised March 16, 2009; accepted March 19, 2009
}

\begin{abstract}
An effective and economic process for removing arsenic in waste water which is acuminating in the process of etching, cutting and washing in semiconductor industry has been developed in this paper. The proposed technique of arsenic removal is as follows: first pretreatment step is to oxidize arsenite to arsenate by potassium permanganate, second key step is precipitation based on arsenic compound solubility with ferric sulfate and slaked lime under $\mathrm{pH}$ adjustment, and the last complementary step is followed by the adsorption of the bentonite with enhanced by activated carbon and organic adsorbent. Experimental results show that under the optimal condition the removal efficiency of arsenic in the waste water is better than $99.99 \%$, or the concentration of arsenic is from its original $100 \mathrm{mg} / \mathrm{l}$ reduced to less than $10 \mu \mathrm{g} / \mathrm{l}$ accordingly.
\end{abstract}

Keywords: Arsenic, Precipitation, Adsorption, Waste Water, Semiconductor Manufacturing

\section{Introduction}

With the fast increasing requirements of the society and economy, the semiconductor industry is being under strong development. A major environment problem resulted by the compound semiconductor manufacturing is its waste water, which most commonly consist of elements such as arsenic, gallium, indium and phosphorous. These elements dissolve in water in the process of cutting, etching, grinding and lead risk to ecological system [1].

The main purpose of this study is to look for an effective process to reduce arsenic in waste water to level acceptable for water reuse or discharge. After comparing various techniques [2-4], i.e., precipitation, adsorption, ion exchange, reverse osmosis, distillation, evaporation, and electrolysis respectively, a combinative process of precipitation and adsorption has been chosen for its economics and convenience.

\section{Materials and Methods}

\subsection{Materials}

The waste water samples are collected at a local com-

"Corresponding author. pound semiconductor factory in September 2006. Several original major contents are: As of $100 \mathrm{mg} / \mathrm{l}, \mathrm{pH}$ of 6, and a little of $\mathrm{Ga}(20 \mathrm{mg} / \mathrm{l})$ and $\mathrm{In}(5 \mathrm{mg} / \mathrm{l})$.

Arsenic and other heavy metals in water samples are analyzed by the atomic adsorption spectrometer (AA-70, HP, U. S.). The $\mathrm{pH}$ is detected by the $\mathrm{pH}$ instrument (PHS-25, Shanghai).

The bentonite is H-type come from Weifang, Shandong. The activated carbon is STR-type come from Shijiazhuang, Hebei. The organic adsorbent is unique made in this study which mainly consisted of vegetable protein. And all of the chemical reagents are of chemical analysis grade.

\subsection{Methods}

The procedure design for removal of arsenic in waste water is shown in Figure 1.

Because the removal efficiency of arsenate is 30\% higher than that of arsenite, $\mathrm{KMnO}_{4}$ has been selected to oxidize $\mathrm{As}(\mathrm{III})$ to $\mathrm{As}(\mathrm{V})$ at the beginning which guaranties $\mathrm{As}(\mathrm{V})$ is dominant in solution in the continues steps [2,3].

Slaked lime $\left(\mathrm{Ca}(\mathrm{OH})_{2}\right)$ have been applied in $\mathrm{pH}$ adjustment and precipitation cooperated with ferric sulfate 


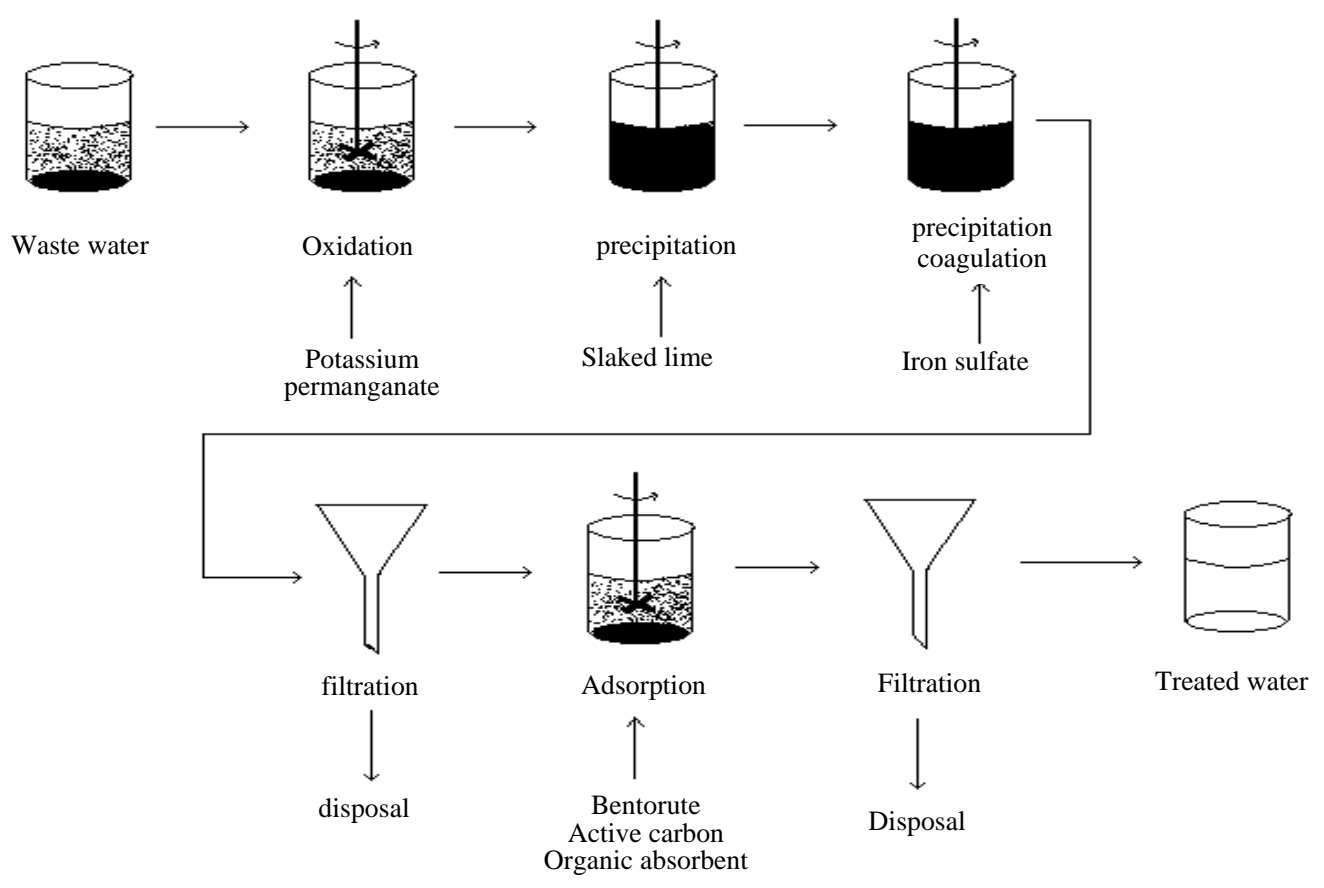

Figure 1. Treatment procedure design.

$\left(\mathrm{Fe}_{2}\left(\mathrm{SO}_{4}\right)_{3}\right)$, because of the high efficiency of the removal of arsenic based on the low solubility of $\mathrm{Ca}_{3}\left(\mathrm{AsO}_{4}\right)_{2} \cdot 3 \mathrm{H}_{2} \mathrm{O}$ (solubility of 0.013 ), $\mathrm{Ca}_{3}\left(\mathrm{AsO}_{4}\right)_{2} \cdot \mathrm{Ca}(\mathrm{OH})_{2}$ (solubility of 0.0023-0.0048), and $\mathrm{FeAsO}_{4} \cdot 2 \mathrm{H}_{2} \mathrm{O}$ (insoluble) [4].

Bentonite has been considered to complement removal of arsenic, which enhanced by activated carbon and organic adsorbent $[2,5,6]$. Bentonite can reach its absorbing equilibrium quickly with good saturated adsorption amount, and the most important is that it is cost-efficient and easy to obtain. Activated carbon is a classical kind of adsorbent with better saturated adsorption amount, and it is used in a broad way presently. The unique organic absorbent is more effective in the removal of arsenic, and it is easy to produce but a little expensive compared to the two adsorbents above mentioned.

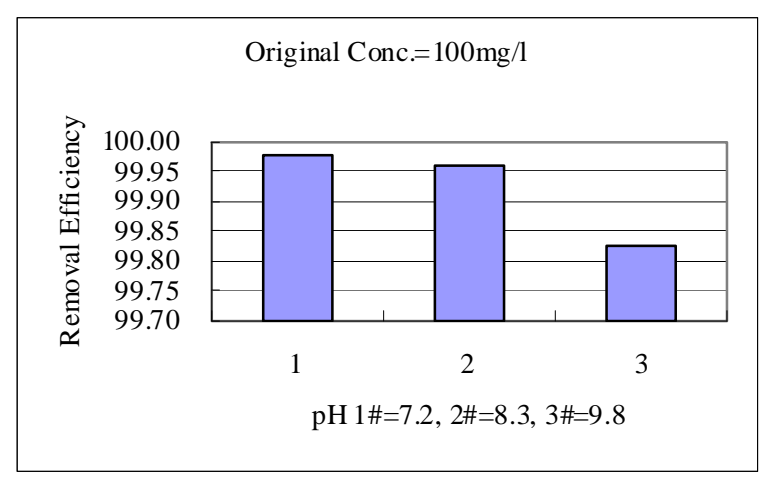

Figure 2. As removal efficiency under different $\mathrm{pH}$.

\section{Results and Discussion}

\subsection{The Removal Efficiency of $\mathrm{Ca}(\mathrm{OH})_{2}$ and $\mathrm{Fe}_{2}\left(\mathrm{SO}_{4}\right)_{3}$}

After pre-treatment of oxidation, a batch experiment has been taken on the composition of $\mathrm{Ca}(\mathrm{OH})_{2}$ and $\mathrm{Fe}_{2}\left(\mathrm{SO}_{4}\right)_{3}$. The results are shown in Table 1.

From the results (Figure 2) it indicates that $\mathrm{pH}$ is a controlled element in this step. If the $\mathrm{Ca}(\mathrm{OH})_{2}$ is over added the excessive $\mathrm{OH}^{-}$can replace $\mathrm{AsO}_{4}{ }^{3-}$ and make $\mathrm{AsO}_{4}{ }^{3-}$ dissolve out from the sludge and adsorbent. From the experiment it shows the suitable composition is $0.2 \mathrm{~g}$ of $\mathrm{Ca}(\mathrm{OH})_{2}$ and $1 \mathrm{ml}$ of $\mathrm{Fe}_{2}\left(\mathrm{SO}_{4}\right)(30 \%)$ for $100 \mathrm{ml}$ of waste water as well as keeping the $\mathrm{pH}$ at neutrality.

Table 1. The batch test of $\mathrm{Ca}(\mathrm{OH})_{2}$ and $\mathrm{Fe}_{2}\left(\mathrm{SO}_{4}\right)_{3}$.

\begin{tabular}{cccc}
\hline $\begin{array}{c}\text { Original As } \\
(\mathrm{mg} / \mathrm{l})\end{array}$ & $\begin{array}{c}\mathrm{Ca}(\mathrm{OH})_{2} \\
(\mathrm{~g} / 100 \mathrm{ml})\end{array}$ & $\begin{array}{c}\mathrm{Fe}_{2}\left(\mathrm{SO}_{4}\right)_{3}(30 \%) \\
(\mathrm{ml} / 100 \mathrm{ml})\end{array}$ & $\begin{array}{c}\text { Remaining As } \\
(\mu \mathrm{g} / \mathrm{l})\end{array}$ \\
\hline 100 & 0.025 & 0.125 & 154.3 \\
100 & 0.05 & 0.25 & 119.4 \\
100 & 0.075 & 0.375 & 90.2 \\
100 & 0.1 & 0.5 & 56.6 \\
100 & 0.125 & 0.625 & 37.8 \\
100 & 0.15 & 0.75 & 24.3 \\
100 & 0.175 & 0.875 & 15.9 \\
100 & 0.2 & 1.0 & 13.7 \\
100 & 0.225 & 1.125 & 13.8 \\
\hline
\end{tabular}


The arsenic in waste water can be reduced from $100 \mathrm{mg} / \mathrm{l}$ to $13.7 \mu \mathrm{g} / \mathrm{l}$ under the optimal precipitation condition, which is quite close to the final requirement.

\subsection{The Removal Capacity of Bentonite}

A batch experiment has been taken to test the adsorption capacity of bentonite. Twelve samples of $100 \mathrm{ml}$ solution which contain arsenic from $5 \mathrm{mg} / \mathrm{l}$ to $60 \mathrm{mg} / \mathrm{l}$ are added by $1 \mathrm{~g}$ of bentonite separately. After stirring for $60 \mathrm{~min}-$ utes under room temperature, the remaining arsenic in water of each sample is detected. The results are shown in Table 2 and Figure 3.

Based on Figure 3 it can be summarized that the saturated arsenic adsorption amount of bentonite is about $5.1 \mathrm{mg} / \mathrm{g}$.

Based on the same method, the saturated arsenic adsorption amount of activated carbon $(18.3 \mathrm{mg} / \mathrm{g})$ and organic adsorbent $(21.2 \mathrm{mg} / \mathrm{g})$ are also obtained.

\subsection{The Optimal Condition for Removal of Arsenic}

To find the optimal condition for removal of arsenic in waste water, a batch experiment has been taken on the proportions of chemicals and adsorbents added. Suppose 1 unit of $\mathrm{Ca}(\mathrm{OH})_{2}$ is represented by $0.10 \mathrm{~g}, 1$ unit of $\mathrm{Fe}_{2}\left(\mathrm{SO}_{4}\right)_{3}(30 \%)$ is represented by $0.50 \mathrm{ml}, 1$ unit of bentonite is represented by $0.175 \mathrm{~g}, 1$ unit of activated carbon

Table 2. The batch test of bentonite.

\begin{tabular}{cccc}
\hline $\begin{array}{c}\text { Original As } \\
(\mathrm{mg} / \mathrm{l})\end{array}$ & $\begin{array}{c}\text { Remain As } \\
(\mu \mathrm{g} / \mathrm{l})\end{array}$ & $\begin{array}{c}\text { Original As } \\
(\mathrm{mg} / \mathrm{l})\end{array}$ & $\begin{array}{c}\text { Remaining As } \\
(\mu \mathrm{g} / \mathrm{l})\end{array}$ \\
\hline 5 & 4.7 & 35 & 30.5 \\
10 & 8.8 & 40 & 35.1 \\
15 & 12.9 & 45 & 40.02 \\
20 & 17.1 & 50 & 44.97 \\
25 & 21.4 & 55 & 49.9 \\
30 & 25.9 & 60 & 54.89 \\
\hline
\end{tabular}

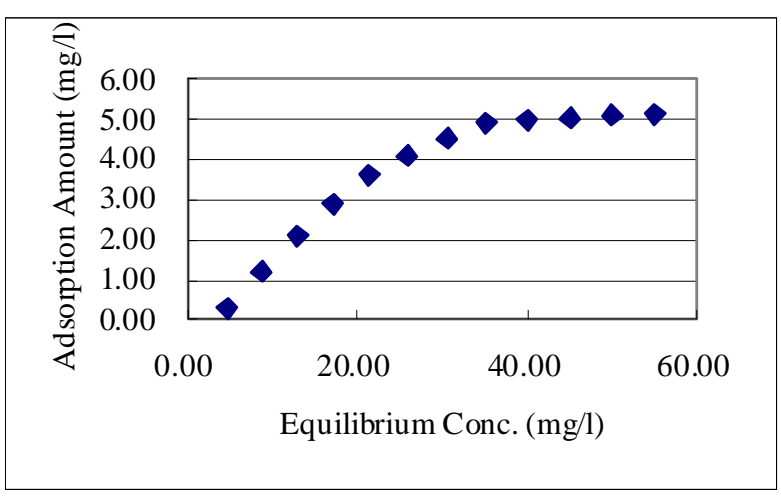

Figure 3. The adsorption equilibrium curve of bentonite. is represented by $0.100 \mathrm{~g}$, and 1unit of organic adsorbent is represented by $0.025 \mathrm{~g}$. The results are shown in Table 3 .

It can be concluded that fourteen composition (No.2, 3, $5,6,8,9,12,13,14,15,18,19,20$, and 21) can meet the requirement of arsenic in treated water should be reduced to less than $10 \mu \mathrm{g} / \mathrm{l}$. After consideration both of the economic and technique factors, No.2 is chosen to be the optimal composition for our procedure.

In addition, the process is also efficient to remove gallium and indium in the waste water. After treated the concentrations of gallium and indium are from original $20 \mathrm{mg} / \mathrm{l}$ and $5 \mathrm{mg} / \mathrm{l}$ respectively reduced to lower than the detecting limit of AA analysis.

\section{Conclusions}

For removing arsenic from waste water which is acuminating in the process of etching, cutting and washing in semiconductor manufacturing, a proposed technique is designed based on technique and economic efficiency. The procedure includes: first pretreatment step is to oxidize arsenite to arsenate by potassium permanganate, second key step is precipitation based on arsenic compound solubility with ferric sulfate and slaked lime under $\mathrm{pH}$ adjustment, and the last complementary step is followed by the adsorption of bentonite with enhanced by activated carbon and organic adsorbent.

Table 3. The batch test of removal of arsenic.

\begin{tabular}{|c|c|c|c|c|c|c|}
\hline Number & $\begin{array}{c}\mathrm{Ca}(\mathrm{OH})_{2} \\
\text { (unit) }\end{array}$ & $\begin{array}{c}\mathrm{Fe}_{2}\left(\mathrm{SO}_{4}\right)_{3} \\
\text { (unit) }\end{array}$ & $\begin{array}{c}\text { Bentonite } \\
\text { (unit) }\end{array}$ & $\begin{array}{c}\text { Activated } \\
\text { carbon } \\
\text { (unit) }\end{array}$ & $\begin{array}{l}\text { Organic } \\
\text { adsorbent } \\
\text { (unit) }\end{array}$ & $\begin{array}{c}\text { Remaining } \\
\text { As } \\
(\mu \mathrm{g} / \mathrm{l})\end{array}$ \\
\hline 1 & 1 & 1 & 1 & 1 & 1 & 30.8 \\
\hline 2 & 2 & 2 & 1 & 1 & 1 & 9.8 \\
\hline 3 & 3 & 3 & 1 & 1 & 1 & 6.2 \\
\hline 4 & 1 & 1 & 2 & 2 & 2 & 28.7 \\
\hline 5 & 2 & 2 & 2 & 2 & 2 & 9.2 \\
\hline 6 & 3 & 3 & 2 & 2 & 2 & 5.8 \\
\hline 7 & 1 & 1 & 3 & 3 & 3 & 24.2 \\
\hline 8 & 2 & 2 & 3 & 3 & 3 & 8.9 \\
\hline 9 & 3 & 3 & 3 & 3 & 3 & 4.6 \\
\hline 10 & 1 & 1 & 2 & 1 & 1 & 29.0 \\
\hline 11 & 1 & 1 & 3 & 1 & 1 & 24.3 \\
\hline 12 & 2 & 2 & 1 & 2 & 2 & 9.3 \\
\hline 13 & 2 & 2 & 3 & 2 & 2 & 9.0 \\
\hline 14 & 3 & 3 & 1 & 3 & 3 & 5.0 \\
\hline 15 & 3 & 3 & 2 & 3 & 3 & 4.8 \\
\hline 16 & 1 & 1 & 1 & 2 & 2 & 29.3 \\
\hline 17 & 1 & 1 & 1 & 3 & 3 & 26.5 \\
\hline 18 & 2 & 2 & 2 & 1 & 1 & 9.6 \\
\hline 19 & 2 & 2 & 2 & 3 & 3 & 8.9 \\
\hline 20 & 3 & 3 & 3 & 1 & 1 & 5.5 \\
\hline 21 & 3 & 3 & 3 & 2 & 2 & 5.3 \\
\hline
\end{tabular}


The optimal composition of reagents for removal of arsenic from $100 \mathrm{mg} / \mathrm{l}$ to $10 \mu \mathrm{g} / \mathrm{l}$ in $100 \mathrm{ml}$ solution can be concluded as $0.2 \mathrm{~g}$ of $\mathrm{Ca}(\mathrm{OH})_{2}, 0.1 \mathrm{ml}$ of $\mathrm{Fe}_{2}\left(\mathrm{SO}_{4}\right)_{3}$ (30\%), $0.175 \mathrm{~g}$ of bentonite, $0.1 \mathrm{~g}$ of activated carbon, and $0.025 \mathrm{~g}$ of organic adsorbent.

\section{Acknowledgement}

This work was supported by the Waste Management Education and Research Consortium, U. S., in 2005.

\section{References}

[1] M. Leist, R. J. Casey, and D. Caridi, "The management of arsenic wastes: Problems and prospects," Journal of Hazardous Materials, Vol. 76, pp. 125-138, 2000.

[2] S. Chegrouche and A. Bensmaili, "Removal of Ga (III) from aqueous solution by adsorption on activated bentonite using a factorial design," Water Research, Vol. 36, pp. 2898-2904, 2002.

[3] P. Palfy, E. Vircikova, and L. Molnar, "Processing of arsenic waste by precipitation and solidification," Waste Management, Vol. 19, pp. 55-59, 1999.

[4] X. Meng, G. P. Korfiatis, C. Christodoulatos, and S. Bang, "Treatment of arsenic in Bangladesh well water using a household co-precipitation and filtration system," Water Research, Vol. 35, pp. 2805-2810, 2000.

[5] H. S. Altundogan, S. Altundogan, F. Tumen, and M. Bildik, "Arsenic removal from aqueous solutions by adsorption on red mud,” Waste Management, Vol. 20, pp. 716-767, 2000.

[6] L. Dambies, T. Vincent, and E. Guibal, "Treatment of arsenic-containing solutions using chitosan derivatives: Uptake mechanism and sorption performances," Water Research, Vol. 36, pp. 3699-3710, 2002. 